Article

\title{
Isotopic Indications of Late Pleistocene and Holocene Paleoenvironmental Changes at Boodie Cave Archaeological Site, Barrow Island, Western Australia
}

\author{
Jane Skippington ${ }^{1, *(D)}$, Tiina Manne ${ }^{2}$ and Peter Veth ${ }^{1,3}$ \\ 1 Archaeology, School of Social Science, University of Western Australia, Perth, WA 6009, Australia; \\ peter.veth@uwa.edu.au \\ 2 School of Social Science, University of Queensland, Brisbane, QLD 4072, Australia; t.manne@uq.edu.au \\ 3 Australian Centre for Excellence in Biodiversity and Heritage, University of Wollongong, \\ Wollongong, NSW 2522, Australia \\ * Correspondence: jane.skippington@research.uwa.edu.au
}

check for

updates

Citation: Skippington, J.; Manne, T.; Veth, P. Isotopic Indications of Late Pleistocene and Holocene

Paleoenvironmental Changes at Boodie Cave Archaeological Site, Barrow Island, Western Australia Molecules 2021, 26, 2582. https:// doi.org/10.3390/molecules26092582

Academic Editors:

Margarita Jambrina-Enríquez and Antonio V. Herrera-Herrera

Received: 21 March 2021

Accepted: 26 April 2021

Published: 28 April 2021

Publisher's Note: MDPI stays neutral with regard to jurisdictional claims in published maps and institutional affiliations.

Copyright: (c) 2021 by the authors. Licensee MDPI, Basel, Switzerland. This article is an open access article distributed under the terms and conditions of the Creative Commons Attribution (CC BY) license (https:/ / creativecommons.org/licenses/by/ $4.0 /)$.

\begin{abstract}
This paper presents the first application of mammal tooth enamel carbonate stable isotope analysis for the purpose of investigating late Pleistocene-early Holocene environmental change in an Australian archaeological context. Stable carbon $\left(\delta^{13} \mathrm{C}\right)$ and oxygen $\left(\delta^{18} \mathrm{O}\right)$ isotope ratios were analyzed from archaeological and modern spectacled hare wallaby (Lagorchestes conspicillatus) and hill kangaroo (Osphranter robustus) tooth enamel carbonates from Boodie Cave on Barrow Island in Western Australia. $\delta^{18} \mathrm{O}$ results track the dynamic paleoecological history at Boodie Cave including a clear shift towards increasing aridity preceding the onset of the Last Glacial Maximum and a period of increased humidity in the early to mid-Holocene. Enamel $\delta^{13} \mathrm{C}$ reflects divergent species feeding ecology and may imply a long-term shift toward increasing diversity in vegetation structure. This study contributes new data to the carbonate-isotope record for Australian fauna and demonstrates the significant potential of stable isotope based ecological investigations for tracking paleoenvironment change to inter-strata resolution.
\end{abstract}

Keywords: isotopes; enamel; archaeology; paleoenvironments; herbivores; mammals; macropods; Australia

\section{Introduction}

Boodie Cave is located on Barrow Island in northwest Australia in an area characterized by dynamic precipitation driven by the influence of winter rainfall and tropical cyclones (Figure 1andFigure 2) [1]. Vegetation is dominated by plants utilizing the C4 photosynthetic pathway [2,3]. The archaeological site preserves rich deposits dating from the earliest period of occupation $(\sim 50 \mathrm{ky} \mathrm{BP})$ through the post-glacial marine transgression and subsequent islandization $(\sim 7 \mathrm{ky} \mathrm{BP})[4,5]$. This provides a unique opportunity to reconstruct past environments and examine the complex relationships between ecological vectors and human populations during the site's extensive history.

The notably well-preserved archaeo-fauna assemblages are diverse and contain a varying array of marine and terrestrial resources that suggest a fluctuating mosaic of habitats accompanied broader paleoenvironmental transformations in the area during the late Pleistocene and early Holocene [5,6]. However, the pursuit of further, site-specific paleoenvironmental data is fundamental to expanding understandings of influencing factors including variable precipitation, changing vegetation structure and unstable biological productivity.

Stable isotope geochemistry of archaeological animal tissue represents a well-established, high precision method for extracting local paleoecological data [7-12]. The high mineral content and crystalline characteristics of tooth enamel mean that it is highly resistant to diagenetic alteration and thus optimal for isotopic studies of Pleistocene-age archaeological deposits [13-15]. 


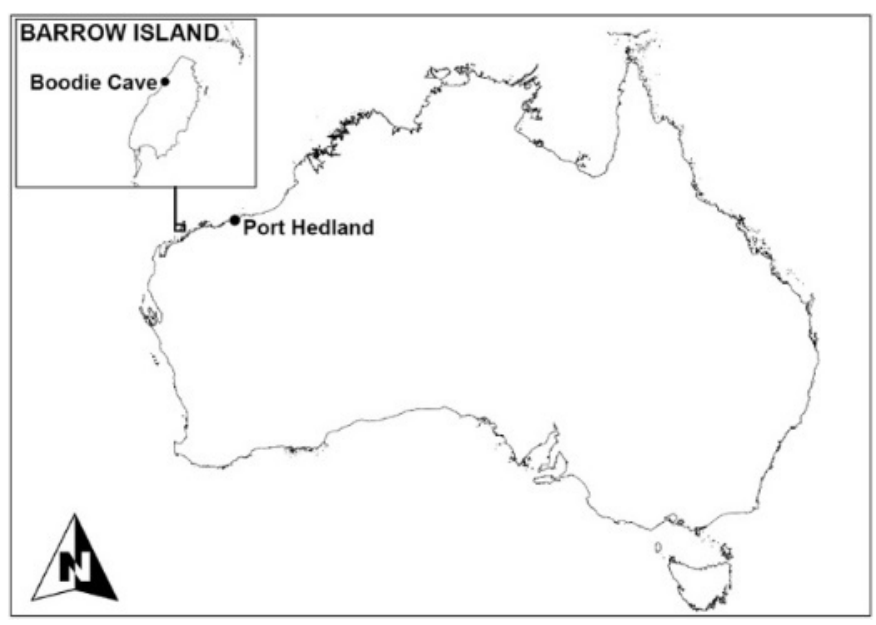

Figure 1. Location of Boodie Cave, Barrow Island, Western Australia.

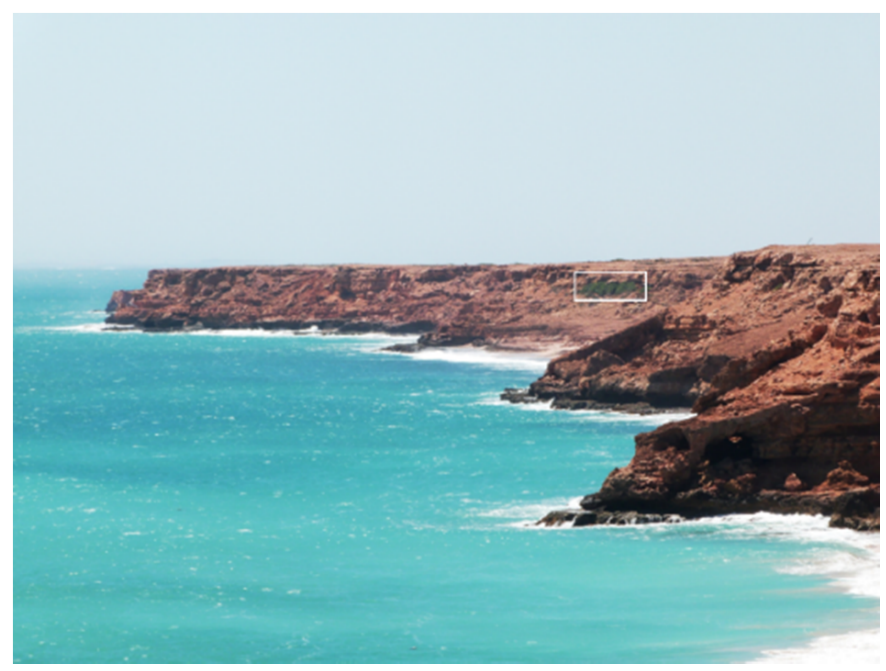

Figure 2. Photograph of Boodie Cave highlighting southwest entrance (Photograph by Peter Veth).

Utilizing established relationships linking enamel $\delta^{13} \mathrm{C}$ to vegetation structure and $\delta^{18} \mathrm{O}$ to relative humidity in macropods $[16,17]$, this study integrates the isotopic compositions of contemporary and archaeological wallabies (Lagorchestes conspicillatus) and kangaroos (Osphranter robustus) with stratigraphic analyses to map changing paleoenvironmental conditions at Boodie Cave through time. While there have been a number of isotopic studies undertaken on modern and fossil tooth enamel of Australian macropods [18-21], this is its first application for creating a high-resolution local isotope record in an archaeological context.

\section{Materials and Methods}

\subsection{Excavation}

A total of ten $1 \mathrm{~m} \times 1 \mathrm{~m}$ squares were excavated at Boodie Cave over the course of three field seasons between 2013 and 2015 (Figure 3) [4]. Excavation was confined to undisturbed areas and undertaken in $2-3 \mathrm{~cm}$ excavation units to a maximum depth of $220 \mathrm{~cm}$. Location features, including stratigraphic units and in situ finds, were mapped and recorded. Excavated material was wet screened and passed through $4 \mathrm{~mm}$ and $2 \mathrm{~mm}$ nested mesh sieves. 


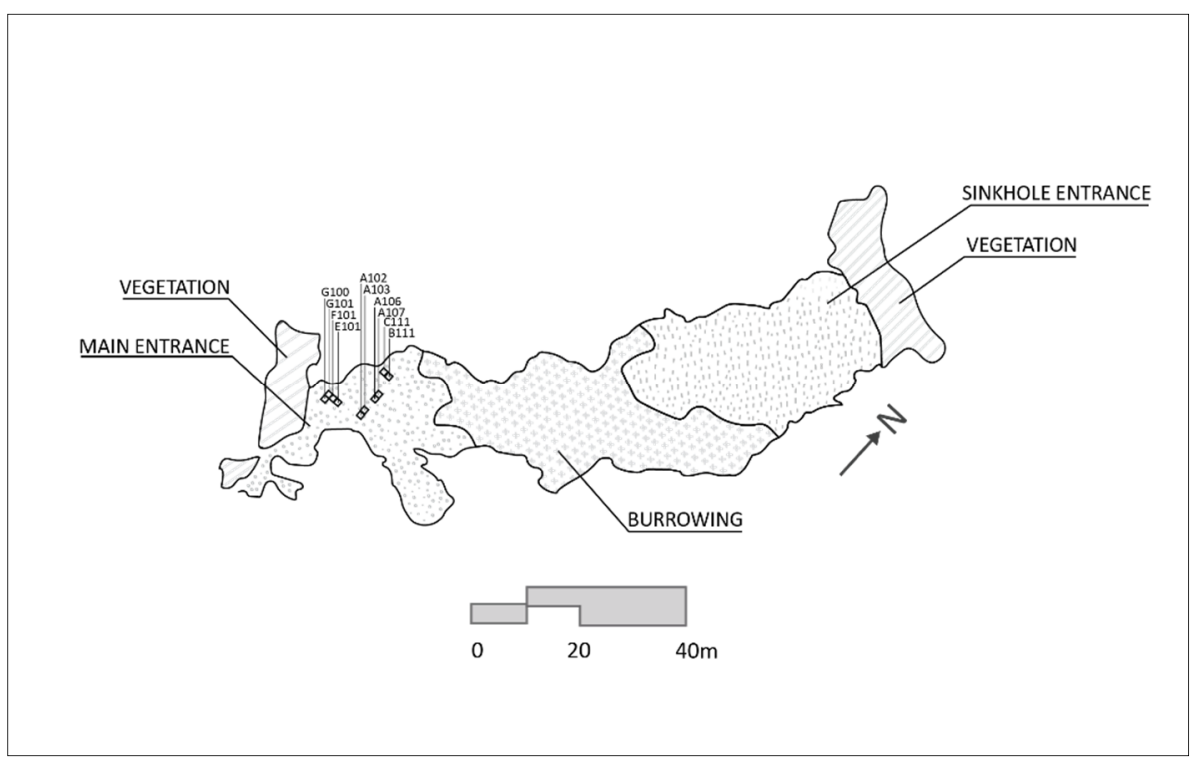

Figure 3. Site plan showing location of squares.

\subsection{Sampling}

Archaeological $(n=56)$ and modern $(n=13)$ L. conspicillatus and O. robustus teeth were collected from the Boodie Cave archaeological site on Barrow Island Western Australia between 2013 and 2015 (Figure 4).

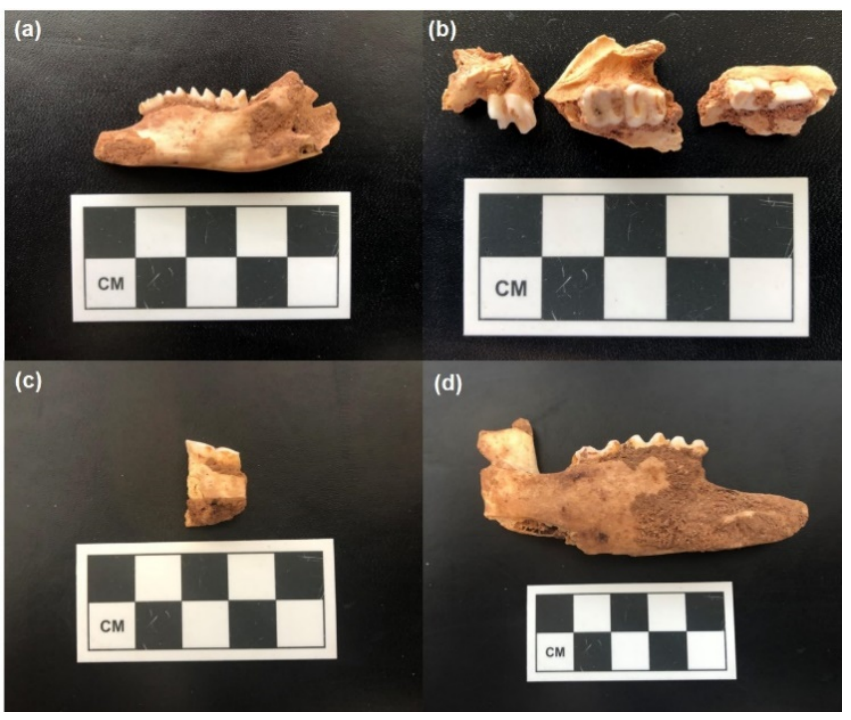

Figure 4. Examples of archaeological macropod teeth used for isotopic analysis from Boodie Cave: (a) right mandible fragment of O. robustus containing P3, M1, M2, M3 (from square G100, stratigraphic unit 3, excavation unit 510); (b) left maxilla fragments of O. robustus containing P3, M1, M2, M3 and M4 (from square G101, stratigraphic unit 3, excavation unit 534); (c) left mandible fragment of L. conspicillatus containing M2 and M3 (from square G101, stratigraphic unit 3, excavation unit 534); (d) left mandible fragment of L. conspicillatus containing M2, M3, and M4 (from square F101, stratigraphic unit 3, excavation unit 409).

Archaeological specimens were identified to taxa and element at the University of Queensland School of Social Science Zooarchaeology laboratory. A modern comparative collection of several (deceased) individuals collected from Barrow Island between 2013 and 2014 facilitated identifications. All specimens were weighed and measured prior to pre-analytical processing. The archaeological material is between $\sim 7$ and $50 \mathrm{ka} \mathrm{BP}[4,5]$. 


\subsection{Preanatyical Processing and Pre-Treatments}

Preanalytical processing was conducted at the University of Western Australian School of Social Science Archaeology laboratory in accordance with contemporary methods [13,22-24]. Tooth enamel from whole teeth was separated from dentine using a Micro Dremel drill fitted with diamond coated drill-bits and subsequently ground into a fine powder using an agate mortar and pestle.

Powdered tooth enamel samples were treated overnight with $50 \mu \mathrm{L}$ of $3 \%$ hydrogen peroxide per $1.0 \mathrm{mg}$ of enamel to remove organic matter. This was followed by a fifteenminute treatment with $0.1 \mathrm{M}$ acetic acid ( $50 \mu \mathrm{L}$ of per $1.0 \mathrm{mg}$ of sample) to remove diagenetic and absorbed carbonate. After each treatment, samples were rinsed with demineralized water, centrifuged four times, and dried in a desiccator.

\subsection{Isotopic Analysis}

Isotopic values are given in per mil (\%) difference in the ratio of heavier to lighter isotopes (R) compared to that of a standard and are expressed using the standard delta notion $(\delta)$ as follows: Rsample Rstandard -

$$
\delta=\left[\left(\frac{\text { Rsample }}{\text { Rstandard }}-1\right)\right] \times 1000
$$

Given that the carbonate phase of macropod tooth enamel is c. $5 \%$, approximately $6 \mathrm{mg}$ samples of treated enamel $\left(0.3 \mathrm{mg}\right.$ of carbonate) were analyzed for $\delta^{13} \mathrm{C}$ and $\delta^{18} \mathrm{O}$. Analyses were undertaken using an GasBench II coupled with Delta XL Mass Spectrometer (Thermo-Fisher Scientific, Bremen, Germany) at the West Australian Biochemistry Centre, School of Plant Biology, University of Western Australia [25]. The isotope results were standardized to the Vienna PeeDee Belemnite (VPDB) and given in per mil (\%o). Threepoints normalization was used in order to reduce raw values to the international scale [26] and normalization was done based on international standards provided by IAEA: LSVEC, NBS19 and NBS18. The external error of $\delta^{13} \mathrm{C}$ analyses is $<0.10 \%$ and $\delta^{18} \mathrm{O}$ is $<0.10 \%$ (1 sd = standard deviation).

\subsection{Statistical Analysis}

Statistical visualizations and analyses were conducted using R. Pairwise Wilcoxon rank sum tests. $p$-values corrected for multiple comparisons are presented.

\section{Results}

\subsection{Carbon Isotopes}

Isotopic measurements were recorded for a total of 69 L. conspicillatus and O. robustus samples. All isotopic results are presented in Table S1 (Supplementary Material). Species mean isotopic results and standard deviations are summarized in Table 1 . Overall $\delta^{13} \mathrm{C}$ values range from $-9.71 \%$ to $-1.11 \%$ (Figure 5$)$. The adjusted $p$-value (0.00004) implies a statistically significant difference between the $\delta^{13} \mathrm{C}$ for L. conspicillatus (mean $=-5.47 \%$, $\mathrm{sd}=1.80$ ) and O. robustus (mean $=-3.42 \%$, sd $=1.57$ ). In general, late formed molars (M3 and $\mathrm{M} 4$ ) recorded higher $\delta^{13} \mathrm{C}$ values than those formed prior to weaning (M1 and M2) (Figure 6). This aligns with a known weaning effect [16].

Stratigraphic units, and corresponding chronological, paleoenvironmental and archeological contexts for Boodie Cave are documented in recent syntheses and summarized in Table $2[4,5,27]$. Comparison did not identify a statistically discernible separation between the archaeological and modern teeth in this study (Figure 7). Equally, no significant interstrata differences were identified. This is true even when a $-1.2 \%$ correction is added to the archaeological specimens to account for depletion in modern ${ }^{13} \mathrm{C}$ resulting from burning of fossil fuels $[28,29]$. While no statistically significant differences were detected between stratigraphic units, $\delta^{13} \mathrm{C}$ associated with the islandization phase trended more negative than signals recorded in layers linked to regression of the shoreline with falling sea levels. 
Table 1. Mean stable carbon and oxygen data for modern and archaeological L. conspicillatus and ${ }^{2}$ O. robustus tooth enamel carbonates.

\begin{tabular}{ccccccc}
\hline Species & Type & $\mathbf{n}$ & $\boldsymbol{\delta}^{\mathbf{1 3}} \mathbf{C}^{\mathbf{1}}$ & $\mathbf{s d}$ & $\boldsymbol{\delta}^{\mathbf{1 8}} \mathbf{O}^{\mathbf{1}}$ & sd \\
\hline \multirow{2}{*}{ L. conspicillatus } & Archaeological & 40 & -5.22 & 1.74 & -0.07 & 1.45 \\
& Modern & 9 & -6.58 & 1.70 & -0.34 & 0.49 \\
\hline \multirow{2}{*}{ O. robustus } & Archaeological & 16 & -3.46 & 1.76 & -0.04 & 0.99 \\
& Modern & 4 & -3.28 & 0.41 & -0.45 & 0.68 \\
\hline
\end{tabular}

${ }^{1}$ All $\delta^{13} \mathrm{C}$ and $\delta^{18} \mathrm{O}$ values given in per mil [\%o, VPDB]. The external error of $\delta^{13} \mathrm{C}$ analyses is $<0.10 \%$ and the external error of $\delta^{18} \mathrm{O}$ is $<0.10 \%$ o $(1 \mathrm{sd}) .2 \mathrm{sd}=$ standard deviation.

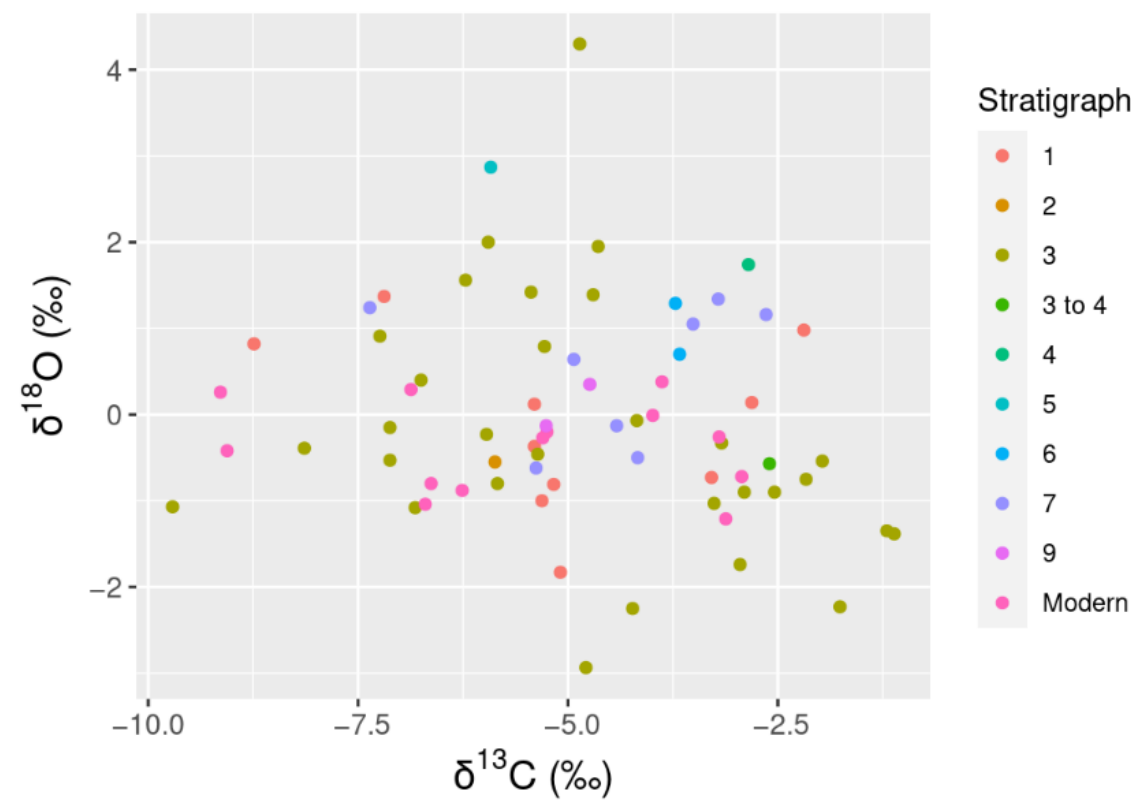

Figure 5. $\delta^{18} \mathrm{O}$ and $\delta^{13} \mathrm{C}$ for L. conspicillatus and O. robustus.

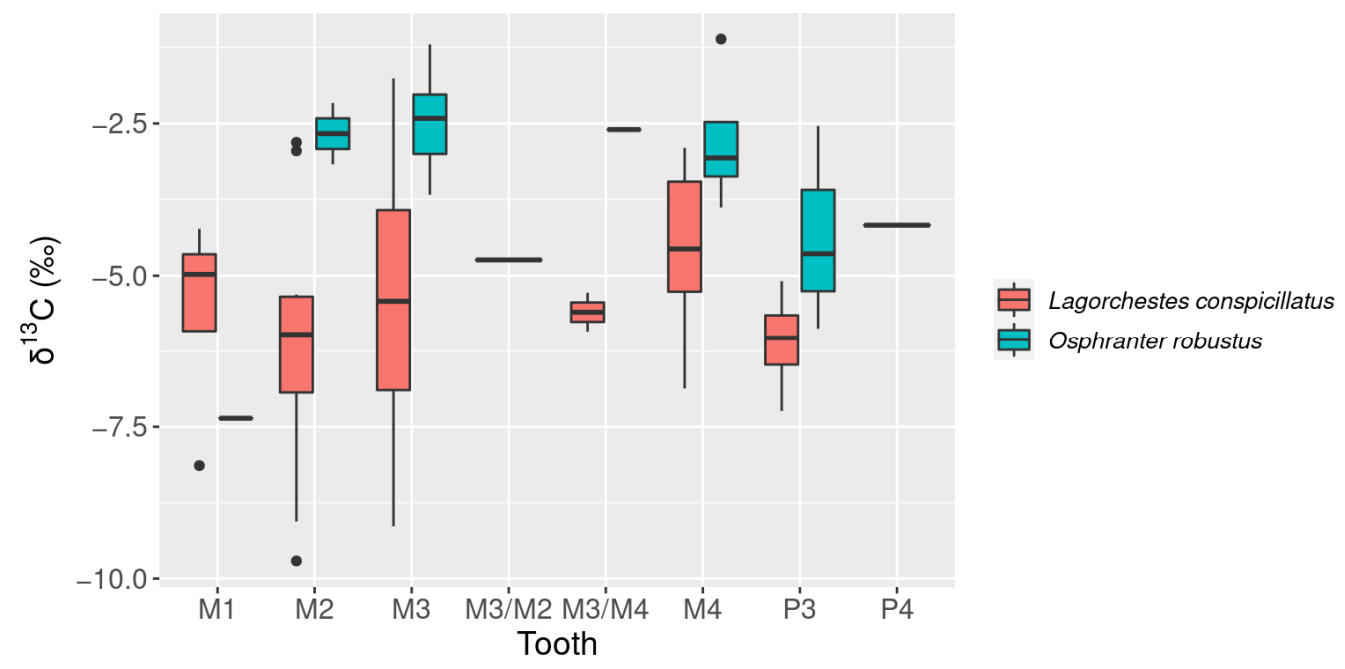

Figure 6. Box plot L. conspicillatus and O. robustus $\delta^{13} \mathrm{C}$ by tooth $(\mathrm{M}=$ molar, $\mathrm{P}=$ premolar $)$. 
Table 2. Stratigraphic unit and corresponding chronological and paleoenvironmental context.

\begin{tabular}{|c|c|c|c|}
\hline Stratigraphic Unit & Chronology (ka BP) ${ }^{1}$ & $\begin{array}{l}\text { Local Paleoenvironmental } \\
\text { Context }^{1}\end{array}$ & $\begin{array}{l}\text { Regional Climate } \\
\text { Context }^{2}\end{array}$ \\
\hline 1 & $1.7-2.5$ & Fully marine (island) & MIS1, Holocene variability \\
\hline 2 & $2.5-6.8$ & Fully marine (island) & \\
\hline 3 & $6.8-7.2$ & Islandization & \\
\hline 4 & $7.2-7.4$ & Islandization & \\
\hline \multirow[t]{2}{*}{5} & $7.4-22.4$ & Transgressing shoreline & $\begin{array}{c}\text { Start of MIS1 at } 14 \mathrm{ka}, \\
\text { deglacial variability }\end{array}$ \\
\hline & & Discontinuity & $\begin{array}{l}\text { MIS2, LGM aridity and complex } \\
\text { glacial response }\end{array}$ \\
\hline 6 & $36.6-42.6$ & Regressing Shoreline & \multirow{2}{*}{$\begin{array}{l}\text { Late MIS3, humid phase, and } \\
\text { initiation of cooler conditions }\end{array}$} \\
\hline \multirow[t]{2}{*}{7} & $42.6-46.2$ & Regressing Shoreline & \\
\hline & & Discontinuity & MIS3 \\
\hline 8 & $46.2-51.1$ & Transgressing Shoreline; cave opens & MIS3 \\
\hline 9 & $\sim 77$ & $\begin{array}{l}\text { Continental-regressing shoreline; } \\
\text { cave closed }\end{array}$ & MIS4 \\
\hline
\end{tabular}

${ }^{1}$ Based on existing archaeological and paleoenvironmental syntheses of Boodie Cave $[4,5] ;{ }^{2}$ Based on synthesis of existing paleoenvironmental data from Australian continent [27].

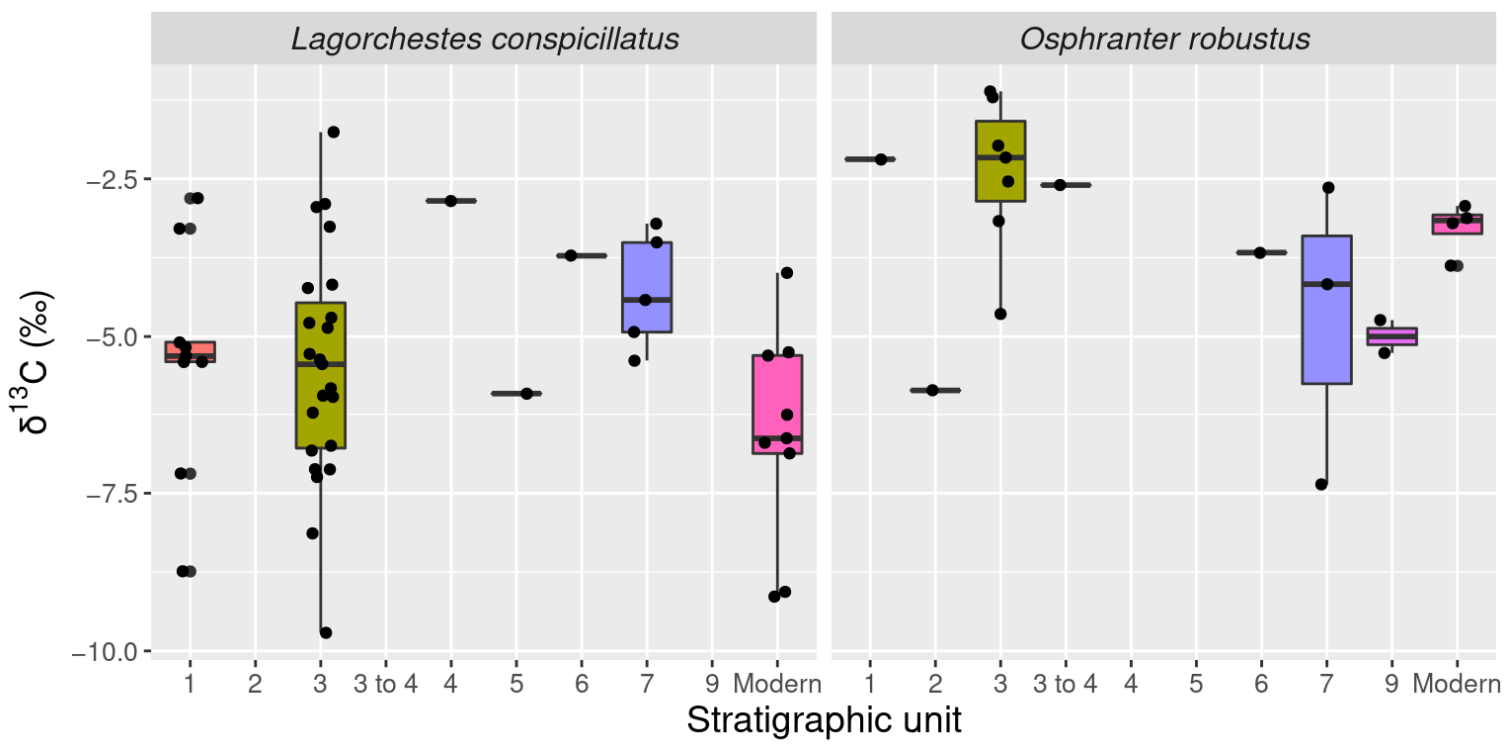

Figure 7. Box plot L. conspicillatus and O. robustus $\delta^{13} \mathrm{C}$ by stratigraphic unit.

\subsection{Oxygen Isotopes}

Measured $\delta^{18} \mathrm{O}$ is statistically indistinguishable between L. conspicillatus (mean $=0.01 \%$, $\mathrm{sd}=1.33)$ and $O$. robustus $($ mean $=-0.12 \%$, sd $=0.93)($ Table 1$)$. Overall $\delta^{18} \mathrm{O}$ values range from $-2.94 \%$ to $4.30 \%$ (Figure 5). This range overlaps the known modern $\delta^{18} \mathrm{O}$ values for Macropus spp. and Osphranter spp. in the wider Carnarvon bioregion (-2.07 to 5.62\%) [17]. Inter-tooth comparison did not identify any notable trends (Figure 8 ). 


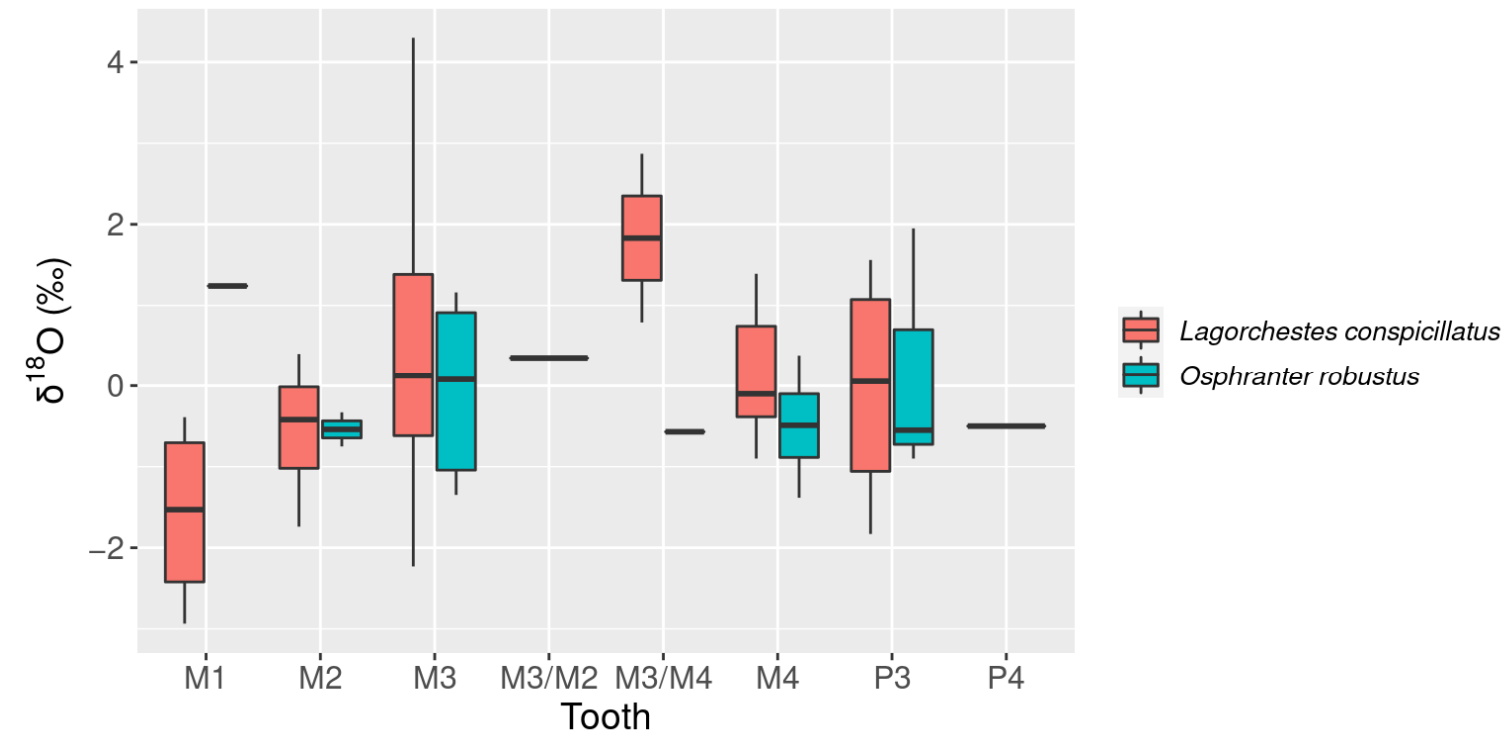

Figure 8. Box plot L. conspicillatus and O. robustus $\delta^{18} \mathrm{O}$ by tooth $(\mathrm{M}=$ molar, $\mathrm{P}=$ premolar $)$.

Inter-stratigraphic analysis identified several significant differences in $\delta^{18} \mathrm{O}$. Stratigraphic units six (mean $=0.10 \%$, sd $=0.42)$ and seven $($ mean $=0.52 \%$, sd $=0.82)$ are both statistically distinct from the modern specimens (mean $=-0.375 \%$, sd $=0.52$ ) (adjusted $p$-values $=0.86 ; 0.88)$ (Figure 9). More broadly, when stratigraphic units were analyzed by chronological context, Late Pleistocene samples pre-dating the Last Glacial Maximum $(\mathrm{LGM})($ mean $=0.53 \%$, sd $=0.72)$ were significantly different when compared to the post LGM Holocene group $($ mean $=-0.17 \%$, sd $=1.37)($ adjusted $p$-value $=0.08)($ Figure 10). Similarly, a statistically notable shift was recorded between modern (mean $=-0.38 \%$, $\mathrm{sd}=0.52)$ and the pre-LGM samples $($ mean $=0.53 \%$, sd $=0.72)($ adjusted $p$-value $=0.01)$.

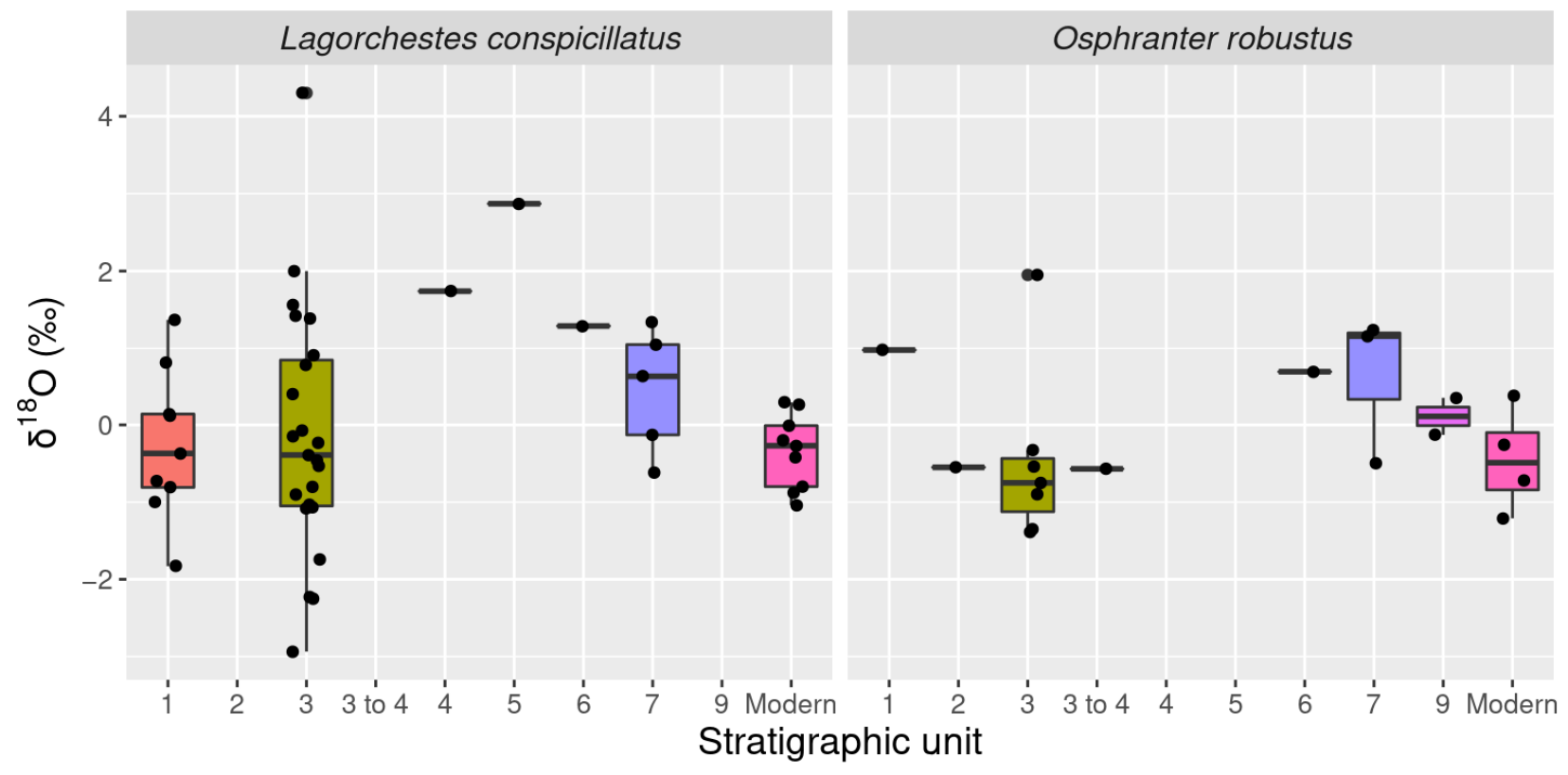

Figure 9. Box plot L. conspicillatus and O. robustus $\delta^{18} \mathrm{O}$ by stratigraphic unit. 


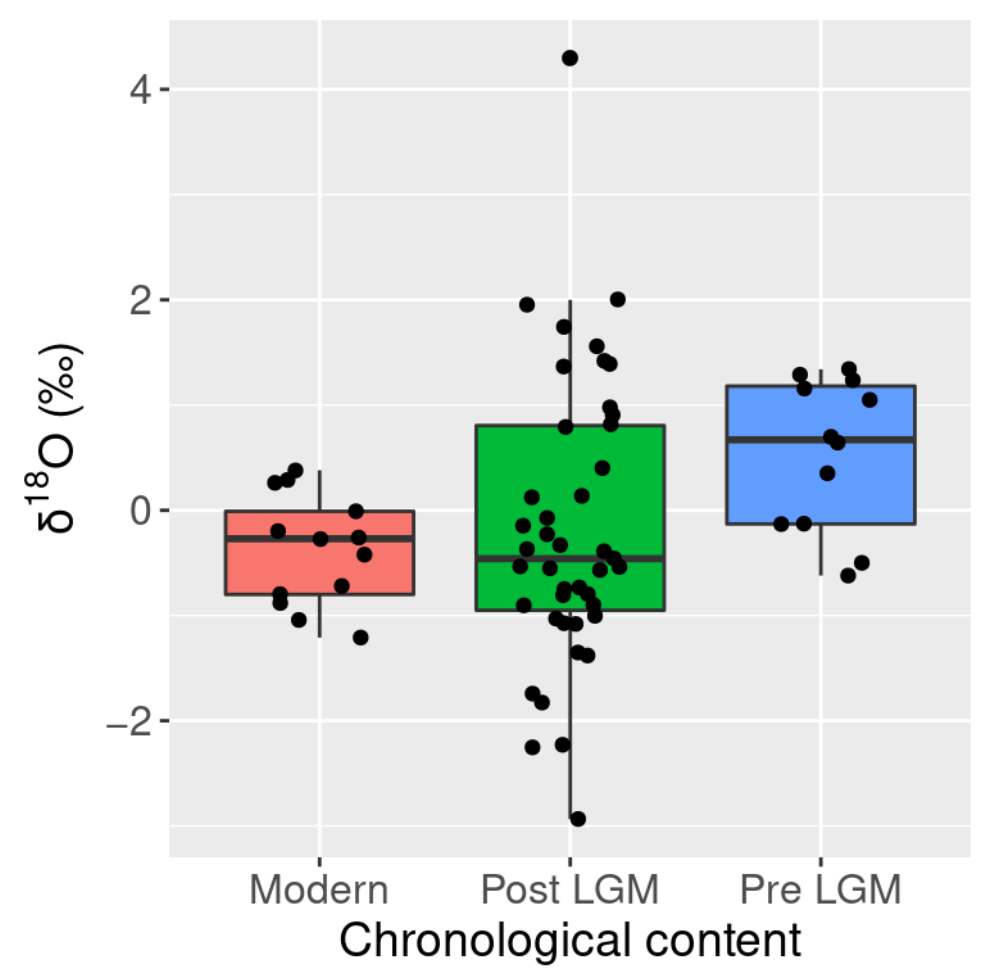

Figure 10. Box plot L. conspicillatus and O. robustus $\delta^{18} \mathrm{O}$ by climatic period.

\section{Discussion}

\subsection{Feeding Ecology and Paleo-Vegetation}

Based on the measured enamel $\delta^{13} \mathrm{C}$ and the known fractionation factor of approximately $12 \%$ [16], dietary $\delta^{13} \mathrm{C}$ for macropods in the study ranged from $-21.71 \%$ to $-13.11 \%$. This implies that the sampled taxa subsisted on a mixed C3 and C4 diet (Table 3) [30,31]. Notably, a clear separation is evident between L. conspicillatus and $O$. robustus. Although this difference may be influenced by the smaller number of $O$. robustus samples, it more likely reflects a dietary divergence. While both subsist on a predominantly C4 diet, results suggest that L. conspicillatus incorporates more C3 into its diet.

Table 3. $\delta^{13} \mathrm{C}_{\text {enamel }}, \delta^{13} \mathrm{C}_{\text {diet and }} \% \mathrm{C} 3$ diet for archaeological and modern taxa.

\begin{tabular}{ccccc}
\hline Species & Type & $\boldsymbol{\delta}^{\mathbf{1 3}} \mathbf{C}_{\text {enamel }}$ & $\boldsymbol{\delta}^{\mathbf{1 3}} \mathbf{C}_{\text {diet }} \mathbf{1}^{\mathbf{1}}$ & \%C3 Diet \\
\hline \multirow{2}{*}{ L. conspicillatus } & Archaeological & -5.22 & -17.22 & $23.00 \%$ \\
& Modern & -6.58 & -18.58 & $32.71 \%$ \\
\hline \multirow{2}{*}{ O. robustus } & Archaeological & -3.46 & -15.46 & $10.43 \%$ \\
& Modern & -3.28 & -15.28 & $9.14 \%$ \\
\hline
\end{tabular}

${ }^{1} \delta^{13} \mathrm{C}_{\text {diet }}$ is calculated by subtracting the known diet-enamel enrichment factor of $12 \%$ from $\delta^{13} \mathrm{C}_{\text {enamel. }} ;{ }^{2} \% \mathrm{C}_{3}$ diet in calculated using the following mixing equation: $f_{1}=\left(\delta_{\text {SAMPLE- }} \delta_{\text {SOURCE2 }}\right) /\left(\delta_{\text {SOURCE1- }} \delta_{\text {SOURCE2 }}\right) \times 100$ where source 1 is the average $\delta^{13} \mathrm{C}$ for $\mathrm{C} 3$ vegetation $\left(-28 \%\right.$ ) and source 2 is the average $\delta^{13} \mathrm{C}$ for $\mathrm{C} 4(-14 \%)[30,31]$.

Given that $70 \%$ of Barrow Island, including the area surrounding Boodie Cave, is characterized by limestone uplands dominated by C4 Triodia wiseana [3], this is interpreted to represent divergent behavioral and feeding strategies rather than distinct habitats. In particular, larger kangaroos species, including $O$. robustus, are widely regarded as preferential grazers that intermittently revert to browsing in arid habitats [32-35].

Conversely, although less is known about the feeding ecology of L. conspicillatus, it is understood that it is a selective feeder prone to browse on a mixture of monocotyledonous and dicotyledonous species including the tips of Triodia spp., shrub foliage and dicot herbs [36-39]. 
While no statistically significant differences were detected between archaeological strata, a number of noteworthy features and trends were identified in the data. In particular, L. conspicillatus $\delta^{13} \mathrm{C}$ associated with the island and islandization phases trended more negative than signals recorded in layers linked to regression of the shoreline, while $O$. robustus signals were more positive in the transgression phase. That is, there is a reversal in the direction of change between species. Given that the island and islandization phases are associated with a climatic period broadly defined by ameliorated conditions (including warmer temperatures, increased precipitation, and improved biological productivity) $[27,40,41]$, it is posited that macropods had access to a wider range of lush vegetation and therefore their opposing tendencies toward graze and browse based diets were magnified due to these environmental shifts.

Even when inter-species difference is taken into account, it is clear that ${ }^{13} \mathrm{C}$ recorded for modern teeth and enamel from more recent archaeological strata (SU1-3) are highly variable compared to earlier pre-LGM layers. Although the noisier signal can be partially attributed to sample size, it is probable that it reflects increased diversity in diet and potentially also in vegetation structure. This is likely the result of heightened variation in biological productivity in the arid zone during the Holocene and increases in sub annual fluctuations in rainfall at the onset of Marine Isotope Stage (MSI) 1 [27,40,42]. Given that C3 and C4 plants have different sensitivity to water availability, diversity of diet also likely contributed to variability in Holocene $\delta^{18} \mathrm{O}$.

\subsection{Paleohumidity}

The lack of discernible statistical difference between $\delta^{18} \mathrm{O}$ for L. conspicillatus and O. robustus supports the expectation that the taxa are utilizing comparable water sources to meet their hydration requirements. Given the lack of free water sources on Barrow Island [43], it is hypothesized that the non-obligate drinkers are primarily obtaining hydration from dietary plant matter $[39,44]$. In addition, the lack of discernible difference between teeth aligns with existing data implying the absence of a weaning effect for $\delta^{18} \mathrm{O}$ and allows for species and molars to be analyzed in bulk [17].

$\delta^{18} \mathrm{O}$ exhibited statistically significant separation between modern samples and the strata associated with the pre-LGM regressing shoreline (SU 6 and SU 7) between 36.6 and $46.2 \mathrm{ka}$ BP. On the basis that the vast majority of physiological and environmental factors that may influence the signal are negated by the environment, this difference is interpreted to reflect changes in relative humidity.

Broadly, the higher $\delta^{18} \mathrm{O}$ associated with late Pleistocene samples implies drier conditions and while contradicting some existing continental and regional models that suggest the late MIS 3 between 40 and 30 ka was predominantly characterized by a humid phase and wetter conditions than the present [27,45], a more recent synthesis by De Deckker et al. 2020 [46] is consistent with significantly increasing aridity leading into the LGM. Conditions were highly variable across the continent and the onset of increasingly arid and cool conditions has been noted in the northern Australia from $35 \mathrm{ka}$ [41]. This variability attests to the relevance of seeking proximal archaeological sources for interpreting paleoenvironments.

In addition, Holocene (post-LGM) $\delta^{18} \mathrm{O}$ was significantly more negative than the late Pleistocene samples. Given that many Holocene samples are derived from stratigraphic unit three and date to between 6.8 and $7.2 \mathrm{ka} \mathrm{BP}$, it is probable that this result aligns with the earliest Holocene low $\delta^{18} \mathrm{O}$ values identified in the regional Cape Range stalagmite record, coinciding with southern Australia mega-lake highstands [1]. Significantly, the archaeology in this period is exceptionally rich indicating intensive site use associated with a humid phase [4]

Importantly, results do not appear to reflect the interaction between mean temperature and relative humidity established by Murphy et al. 2007 [17] but are more strongly linked to known changes in levels of humidity $[27,41]$ 


\section{Conclusions}

Paleoenvironmental signatures in archaeological and modern teeth from the Boodie Cave archaeological site on Barrow Island track shifting climatic conditions and, to a lesser extent, evolving habitats. Shifting $\delta^{13} \mathrm{C}$ potentially implies a slow but progressive increase in vegetation diversity associated with broader climatic amelioration.

Significant inter-strata variation in $\delta^{18} \mathrm{O}$ between modern, Holocene, and late Pleistocene samples broadly aligns with continental and regional models but also contributes to a locate climate record. High $\delta^{18} \mathrm{O}$ values between 36.6 and $46.2 \mathrm{ka} \mathrm{BP}$ demonstrates the local onset of pre-LGM aridity and an early to mid-Holocene low in $\delta^{18} \mathrm{O}$ aligns with an increasingly humid period reflected in regional speleothem records, consistent with existing climate models $[1,46]$.

Fundamentally, this study demonstrates for the first time that isotopic analysis of macropod tooth enamel can be used to track paleoenvironmental shifts to inter-strata resolution in Australian archaeological contexts.

Supplementary Materials: The following is available online: Table S1: Isotopic results for L. conspicillatus and O. robustus.

Author Contributions: Conceptualization, methodology, analysis, and original draft, J.S.; taxa identification, T.M.; review and supervision, T.M. and P.V. All authors have read and agreed to the published version of the manuscript.

Funding: This research was conducted as part of the Barrow Island Archaeological Project and was funded by an ARC Discovery Grant (DP130100802) 2013-2015 awarded to Peter Veth, Tiina Manne, Alistair Paterson, Mark Basgall, David Zeanah and Christa Placzek. Manne's work was also funded by an ARC Discovery Early Career Researcher Award (DE150101597).

Institutional Review Board Statement: Not applicable.

Informed Consent Statement: Not applicable.

Data Availability Statement: Not applicable.

Acknowledgments: Department of Parks and Wildlife (now Department of Biodiversity Conservation and Attractions), WA Oil, and Chevron Australian Business Unit provided personnel and logistical support. Greg Skrzyrpek and Douglas Ford from the West Australian Biochemistry Centre at The University of Western Australia are thanked for technical advice and practical support relating to sample preparation and analyses. Claire Garcia-Webb is acknowledged for assistance with site plan illustration.

Conflicts of Interest: The authors declare no conflict of interest. The funders had no role in the design of the study; in the collection, analyses, or interpretation of data; in the writing of the manuscript, or in the decision to publish the results.

Sample Availability: Samples of the compounds are not available from the authors.

\section{References}

1. Denniston, R.F.; Asmerom, Y.; Lachniet, M.; Polyak, V.J.; Hope, P.; An, N.; Rodzinyak, K.; Humphreys, W.F. A Last Glacial Maximum through middle Holocene stalagmite record of coastal Western Australia climate. Quat. Sci. Rev. 2013, 77, 101-112. [CrossRef]

2. Hattersley, P.W. The distribution of C3 and C4 grasses in Australia in relation to climate. Oecologia 1983, 57, 113-128. [CrossRef]

3. Short, S.; Turner, B. Distribution and Abundance of Spectacled Hare-wallabies and Euros on Barrow Island, Western Australia. Wildl. Res. 1991, 18, 421-429. [CrossRef]

4. Veth, P.; Kendrick, P.; Ward, I.; Manne, T.; Ulm, S.; Ditchfeild, K.; Dortch, J.; Hook, F.; Petchey, F.; Hogg, A.; et al. Early human occupation of a Maritime Desert, Barrow Island, North-West Australia. Quat. Sci. Rev. 2017, 168, 19-29. [CrossRef]

5. Ward, I.; Veth, P.; Prossor, L.; Denham, T.; Ditchfeild, K.; Manne, T.; Kendrick, P.; Byrne, C.; Hook, F.; Troitzsch, U. 50,000 years of archaeological site stratigraphy and micromorphology in Boodie Cave, Barrow Island, Western Australia. J. Archaeol. Sci. Rep. 2017, 15, 344-369. [CrossRef]

6. Manne, T.; Veth, P.M. Late Pleistocene and early Holocene exploitation of estuarine communities in northwestern Australia. Quat. Int. 2015, 385, 112-123. [CrossRef] 
7. Balasse, M.; Ambrose, S. The seasonal mobility model for prehistoric herders in the south-western cape of south Africa assessed by isotopic analysis of sheep tooth enamel. J. Archaeol. Sci. 2002, 29, 917-932. [CrossRef]

8. Balasse, M.; Smith, A.B.; Ambrose, S.H.; Leigh, S.R. Determining sheep birth seasonality by analysis of tooth enamel oxygen isotope ratios: The late Stone Age site of Kasteelberg (South Africa). J. Archaeol. Sci. 2003, 30, 205-215. [CrossRef]

9. Cerling, T.E.; Harris, J.M. Carbon isotope fractionation between diet and bioapatite in ungulate mammals and implications for ecological and paleoecological studies. Oecologia 1999, 120, 347-363. [CrossRef] [PubMed]

10. Clementz, M.T. New Insights from Old Bones: Stable Isotope Analysis of Fossil Mammals. Am. Soc. Mammal. 2012, 93, 368-380. [CrossRef]

11. Fraser, R.A.; Grun, R.; Privat, K.; Gagan, M.K. Stable-isotope microprofiling of wombat tooth enamel records seasonal changes in vegetation and environmental conditions in eastern Australia. Palaeogeogr. Palaeoclimatol. Palaeoecol. 2008, 269, 66-77. [CrossRef]

12. Pilaar Birch, S.E. Stable isotopes in zooarchaeology: An introduction. Archaeol. Anthropol. Sci. 2013, 5, 81-83. [CrossRef]

13. Balasse, M. Reconstructing dietary and environmental history from enamel isotopic analysis: Time resolution of intra-tooth sequential sampling. Int. J. Osteoarchaeol. 2002, 12, 155-165. [CrossRef]

14. Koch, P. Isotopic Studies of the Biology of Modern and Fossil Vertebrates. In Stable Isotopes in Ecology and Environmental Science; Michener, R., Lajtha, K., Eds.; Blackwell Publishing: Oxford, UK, 2007; pp. 99-154.

15. Wang, Y.; Cerling, T.E. A model of fossil tooth and bone diagenesis: Implications for paleodiet reconstruction from stable isotopes. Palaeogeogr. Palaeoclimatol. Palaeoecol. 1994, 107, 281-289. [CrossRef]

16. Murphy, B.P.; Bowman, D.M.J.S.; Gagan, M.K. Sources of carbon isotope variation in kangaroo bone collagen and tooth enamel. Geochim. Cosmochim. Acta 2007, 71, 3847-3858. [CrossRef]

17. Murphy, B.P.; Bowman, D.M.J.S.; Gagan, M.K. The interactive effect of temperature and humidity on the oxygen isotope composition of kangaroos. Funct. Ecol. 2007, 21, 757-766. [CrossRef]

18. Prideaux, G.J.; Long, J.A.; Ayliffe, L.K.; Hellstrom, J.C.; Pillans, B.; Boles, W.E.; Hutchinson, M.N.; Roberts, R.G.; Cupper, M.L.; Arnold, L.J.; et al. An arid-adapted middle Pleistocene vertebrate fauna from south-central Australia. Nature 2007, 445, 422-425. [CrossRef]

19. Forbes, M.S.; Kohn, M.J.; Bestland, E.A.; Wells, R.T. Late Pleistocene environmental change interpreted from $\delta 13 \mathrm{C}$ and $\delta 18 \mathrm{O}$ of tooth enamel from the Black Creek Swamp Megafauna site, Kangaroo Island, South Australia. Palaeogeogr. Palaeoclimatol. Palaeoecol. 2010, 291, 319-327. [CrossRef]

20. Brookman, T.H.; Ambrose, S.H. Seasonal variation in kangaroo tooth enamel oxygen and carbon isotopes in southern Australia. Quat. Res. 2012, 78, 256-265. [CrossRef]

21. Montanari, S.; Louys, J.; Price, G. Pliocene paleoenvironments of Southeastern Queensland, Australia inferred from stable isotopes of marsupial tooth enamel. PLoS ONE 2013, 8, e66221. [CrossRef]

22. Garvie-Lok, S.J.; Varney, T.L.; Katzenberg, M.A. Preparation of bone carbonate for stable isotope analysis: The effects of treatment time and acid concentration. J. Archaeol. Sci. 2004, 31, 763-776. [CrossRef]

23. Koch, P.L.; Tuross, N.; Fogel, M.L. The effects of sample treatment and diagenesis on the isotopic integrity of carbonate in biogenic hydroxylapatite. J. Archaeol. Sci. 1997, 24, 417-429. [CrossRef]

24. Skippington, J.; Veth, P.; Manne, T.; Slack, M. Preanalytical processing of archaeological mammal enamel apatite carbonates for stable isotope investigations: A comparative analysis of the effect of acid treatment on samples from Northwest Australia. International. Int. J. Osteoarchaeol. 2019, 29, 760-771. [CrossRef]

25. Paul, D.; Skrzypek, G. Assessment of carbonate-phosphoric acid analytical technique performed using GasBench II in continuous flow isotope ratio mass spectrometry. Int. J. Mass Spectrom. 2007, 262, 180-186. [CrossRef]

26. Skrzypek, G. Normalization procedures and reference material selection in stable HCNOS isotope analyses-An overview. Anal. Bioanal. Chem. 2013, 405, 2815-2823. [CrossRef]

27. Fitzsimmons, K.E.; Cohen, T.J.; Hesse, P.P.; Jansen, J.; Nanson, G.C.; May, J.; Barrows, T.T.; Haberlah, D.; Hilgers, A.; Kelly, T.; et al. Late Quaternary palaeoenvironmental change in the Australian drylands. Quat. Sci. Rev. 2013, 74, 78-96. [CrossRef]

28. Friedli, H.; Loetscher, H.; Oeschger, H.; Siegenthaler, U.; Stauffer, B. Ice core record of the $13 \mathrm{C} / 12 \mathrm{C}$ ratio of atmospheric $\mathrm{CO}_{2}$ in the past two centuries. Nature 1986, 324, 237-238. [CrossRef]

29. Leuenberger, M.; Siegenthaler, U.; Langway, C. Carbon isotope compositionof atmospheric $\mathrm{CO}_{2}$ during the last ice age from an Antarctic ice core. Nature 1992, 357, 488-490. [CrossRef]

30. O'Leary, M. Carbon isotopes in photosynthesis. Bioscience 1988, 38, 328-336. [CrossRef]

31. Johnson, B.J.; Miller, G.H.; Fogel, M.L.; Beaumont, P.B. The determination of late Quaternary paleoenvironments at Equus Cave, South Africa, using stable isotopes and amino acid racemization in ostrich eggshell. Palaeogeog. Palaeoclim. Palaeoecol. 1997, 136, 121-137. [CrossRef]

32. Ealey, E.H.M. Ecology of the Euro, Macropus robustus (Gould) in north-western Australia: Age and growth. CSIRO Wildl. Res. 1967, 12, 67-80. [CrossRef]

33. Hume, I. Digestive Physiology and Nutrition of Marsupial; Cambridge University Press: London, UK, 1982.

34. Jackson, S. Australian Mammals: Biology and Captive Management; CSIRO Publishing: Collingwood, Australia, 2003.

35. Jackson, S.; Groves, C. Taxonomy of Australian Mammals; CSIRO Publishing: Clayton, Australia, 2015.

36. Main, A.R.; Yadav, M. Conservation of macropods in reserves in Western Australia. Biol. Conserv. 1971, 3, 123-133. [CrossRef] 
37. Burbidge, A.A.; Johnson, K.A. Spectacled Hare-wallaby, Lagorchestes conspicillatus. In Complete Book of Australian Mammals; Strahan, R., Ed.; Angus and Robertson: Sydney, Australia, 1983; pp. 197-198.

38. Lngleby, S.; Westoby, M. Habitat Requirements of the Spectacled Hare-wallaby (Lagorchestes conspicillatus) in the Northern Territory and Western Australia. Wildl. Res. 1992, 19, 721-741. [CrossRef]

39. Strahan, R. (Ed.) The Mammals of Australia; Reed Books: Chatswood, Australia, 1995.

40. Morton, S.R.; Smith, D.M.S.; Dickman, C.R.; Dunkerley, D.L.; Friedel, M.H.; McAllister, R.R.J.; Reid, J.R.W.; Roshier, D.A.; Smith, M.A.; Walsh, F.J.; et al. A fresh framework for the ecology of arid Australia. J. Arid Environ. 2011, 75, 313-329. [CrossRef]

41. Williams, A.N.; Veth, P.; Steffan, W.; Ulm, S.; Turney, C.S.; Reeves, J.M.; Phipps, S.J.; Smith, M. A continental narrative: Human settlement patterns and Australian climate change over the last 35,000 years. Quat. Sci. Rev. 2015, 28, 91-112. [CrossRef]

42. van Etten, E.J.B. Inter-annual rainfall variability of arid Australia: Greater than elsewhere? Aust. Geogr. 2009, 40, 109-120. [CrossRef]

43. King, J.M.; Bradshaw, S.D. Stress in an island kangaroo? The Barrow Island euro, Macropus robustus isabellinus. Gen. Comp. Endocrinol. 2010, 167, 60-67. [CrossRef]

44. Ayliffe, L.K.; Chivas, A.R. Oxygen isotope composition of the bone phosphate of Australian kangaroos: Potential as a palaeoenvironmental recorder. Geochim. Cosmochim. 1990, 54, 2603-2609. [CrossRef]

45. Veth, P.; Smith, M.; Bowler, J.M.; Fitzsimmons, K.E.; Williams, A.; Hiscock, P. Excavations at Parnkupirti, Lake Gregory, Great Sandy Desert: OSL ages for occupation before the Last Glacial Maximum. Aust. Archaeol. 2009, 69, 1-10. [CrossRef]

46. De Deckker, P.; Moros, M.; Perner, K.; Blanz, T.; Wacker, L.; Schneider, R.; Barrows, T.T.; O’Loingsigh, T.; Jansen, E. Climatic evolution in the Australian region over the last $94 \mathrm{ka}$-Spanning human occupancy-And unveiling the Last Glacial Maximum. Quat. Sci. Rev. 2020, 249, 106593. [CrossRef] 